\title{
The striking species Apsil pennata Malloch (Diptera, Muscidae)
}

\author{
Luciano Damián Patitucci ${ }^{1} \&$ Márcia Souto Couri²
}

Consejo Nacional de Investigaciones Científicas y Técnicas (CONICET), Buenos Aires, Argentina. Museo Argentino de Ciencias Naturales
"Bernardino Rivadavia", Av. Ángel Gallardo 470, Buenos Aires, Argentina. lpatitu@yahoo.com.ar
²Departmento de Entomologia, Museu Nacional, Quinta da Boa Vista, São Cristóvão, 20940-040 Rio de Janeiro-RJ, Brazil. courimarcia@gmail.com

\begin{abstract}
The striking species Apsil pennata Malloch (Diptera, Muscidae). Apsil pennata Malloch, 1934 is a singular species of a small group of predaceous muscids endemic to Patagonia and southern Chile. We present for the first time the description of the female, illustration of male and female terminalia, notes on their habitat and new records.
\end{abstract}

KEYWORDS. Insecta; morphology; new records; predator; taxonomy.

Apsil Malloch is a small group of predaceous muscids distributed from sea level to the highlands, endemic to Patagonia and southern Chile. This genus is considered monophyletic and close to Reynoldsia Malloch (also endemic to the same areas) according to a cladistic and biogeographic study (de Carvalho \& Couri 2002, 2011).

The genus Apsil was erected by Malloch (1929) with a single species, $A$. maculiventris, and later, seven new species were added (Malloch 1934). Some species were described based only on male or female specimens. Couri (2000, 2002, 2006) revised the genus, and presented redescriptions, illustrations of some male and female terminalia, and added two new species. Information about their biology, habitat and immature stages are unknown.

Apsil pennata was described based on only two male specimens by Malloch (1934). This singular species is distinguished from its congenerics by the striking structure in the fore tibia. Recently, Couri (2000) examined the type specimens and redescribed the male. These specimens were collected in Casa Pangue (Chile) and near Bariloche city (Argentina) in the spring of 1926 (Malloch 1934). Both environments presented large forested areas (Edwards 1929) and are included in the Subantarctic phytogeographic province (Cabrera \& Willink 1973). The species has not been collected since then.

The aim of this contribution is to present, for the first time, the description of the female, illustration of the male terminalia, notes on their habitat, new records and the inclusion of the female in Couri's (2006) key to species.

\section{MATERIAL AND METHODS}

All studied specimens are deposited in the Museo Argentino de Ciencias Naturales "Bernardino Rivadavia" (MACN). The identification of the male specimens was conducted using the original description (Malloch 1934) and redescription (Couri 2000). To study the terminalia morphology, abdomen of se- lected specimens was detached and transferred to $90 \%$ lactic acid for two weeks. After clearing, the genital structures were removed and temporarily mounted on concave glass slides in glycerin. After the study, the dissected parts were placed in a plastic microvial with glycerin and pinned with the respective specimen. The terminology used for the external morphology follows Cumming \& Wood (2009).

\section{TAXONOMY}

\section{Apsil pennata Malloch, 1934}

Apsil pennata Malloch, 1934: 241, figs. 43a-c. Holotype male in the Natural History Museum, London, United Kingdom, and one paratype in National Museum of Natural History, Washington D.C., USA. Typelocality: Chile, Casa Pangue.

Description. Female (Figs. 1-8). Length. Body: 4.9-5.7 mm, wing: 4.6-5.1 mm.

Head (Fig. 2). Dichoptic, frons at vertex about one third of the head width; eyes with anterointernal facets developed and with short hairs. Frons black; fronto-orbital plate black with grey pollinosity; parafacial and gena golden yellow dusted with fine hairs; lateral and posterior portions of the head with grey pollinosity; 3-4 pairs of frontal and 1 pair of reclinate orbital setae. Outer and inner vertical setae developed, as long as ocellar setae. Antenna dark brown with grey pollinosity, apex of pedicel and base of postpedicel yellow, in lateral view inserted at the mid-level of the eye; arista bare. Palpus yellow, with base black, slightly dilated at apex.

Thorax (Fig. 4). Grey. Prescutum with two dark-brown spots between dorsocentral row of setae and notopleuron, and two dark-brown vittae fused behind suture; scutum with a dark-brown central vitta ending at level of the base of the second pair of dorsocentral setae; scutellum dark-brown; anepisternum grey with a dark-brown spot; anepimeron, katepimeron, katepisternum, proepisternum, proepimeron and meron grey; anterior and posterior spiracles grey. Chaetotaxy: acrostichals very thin and short; dorsocentrals 

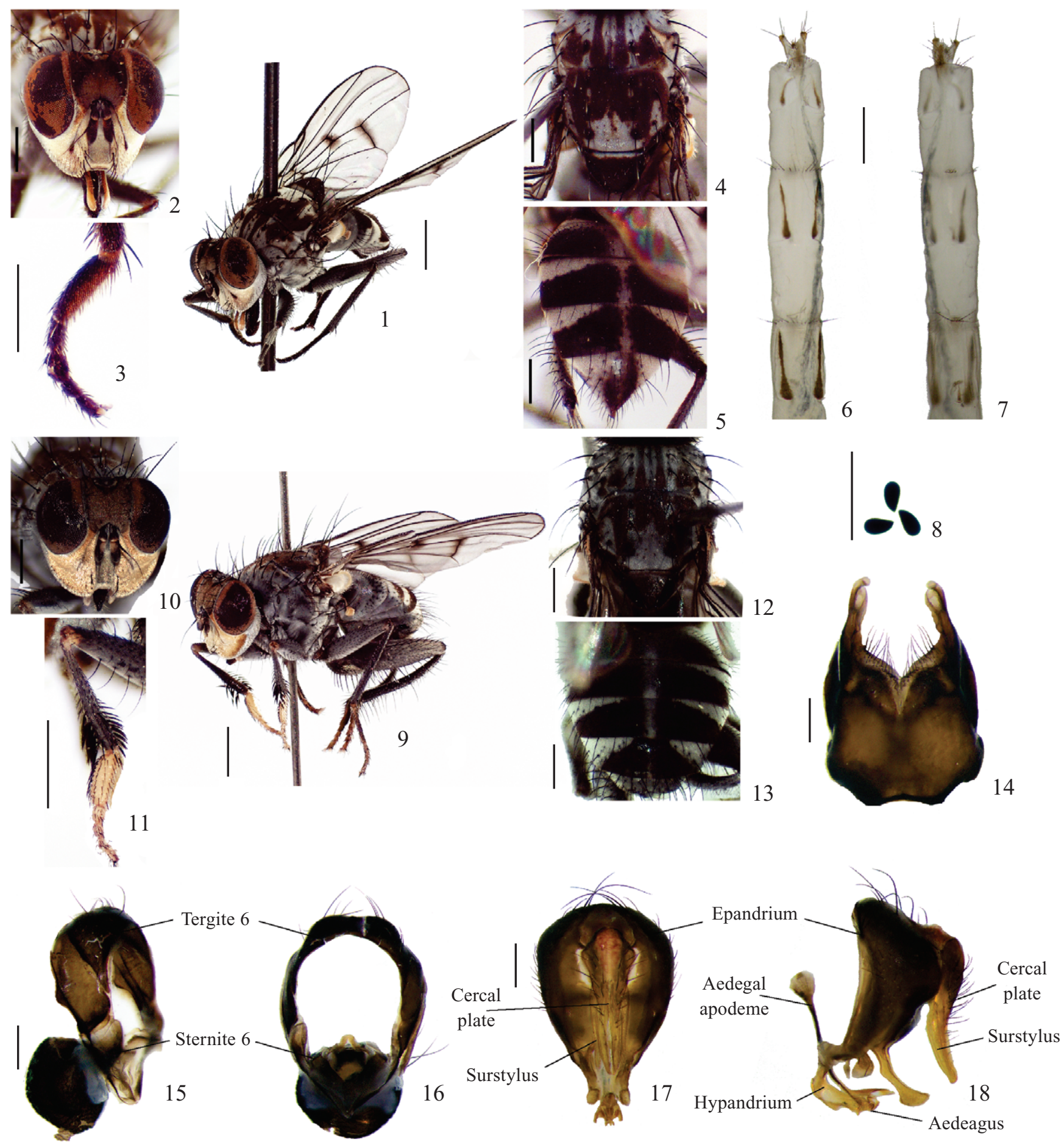

Figs. 1-18. Apsil pennata. 1-8. Female: 1. Fronto-lateral view (scale bar: $1 \mathrm{~mm}$ ). 2. Head, frontal view. 3. Fore tarsus, lateral view. 4. Thorax, dorsal view. 5. Abdomen, dorsal view (scale bars: $0.5 \mathrm{~mm}$ ). 6. Terminalia, dorsal view. 7. Terminalia, ventral view (scale bar: $0.5 \mathrm{~mm}$ ). 8 . Spermathecae (scale bar: $0.5 \mathrm{~mm}$ ). 9-18. Male: 9. Fronto-lateral view (scale bar: $1 \mathrm{~mm}$ ). 10. Head, frontal view. 11. Fore tarsus, lateral view. 12. Thorax, dorsal view. 13. Abdomen, dorsal view (scale bars: $0.5 \mathrm{~mm}$ ). 14. Sternite 5 (scale bar: $0.5 \mathrm{~mm}$ ). 15. Tergite and sternite 6, lateral view. 16. Tergite and sternite 6, dorsal view. 17. Cercal plate and surstyli, dorsal view. 18. Cercal plate, surstyli, hypandrium, and phallic complex, lateral view (scale bar: $0.2 \mathrm{~mm}$ ).

$2+3$; postpronotals 1 ; intra-alars $1+2$; supra-alars 1 ; notopleurals 2 , the posterior a little shorter than the anterior one. Prealar absent. Scutellum with one long basal and one long apical pair of setae, similar in size. Anepisternum with a series of 4-5 strong setae; katepisternals $1+1+1$, forming an equilateral triangle; anepimeron, katepimeron, and meron bare; proepisternals 2; proepimeral 1. Prosternum bare.

Wing. Hyaline; with black marks on both cross veins, veins bare. Both calypters whitish hyaline with yellow margins; lower calypter slightly longer than upper; halter yellow. 


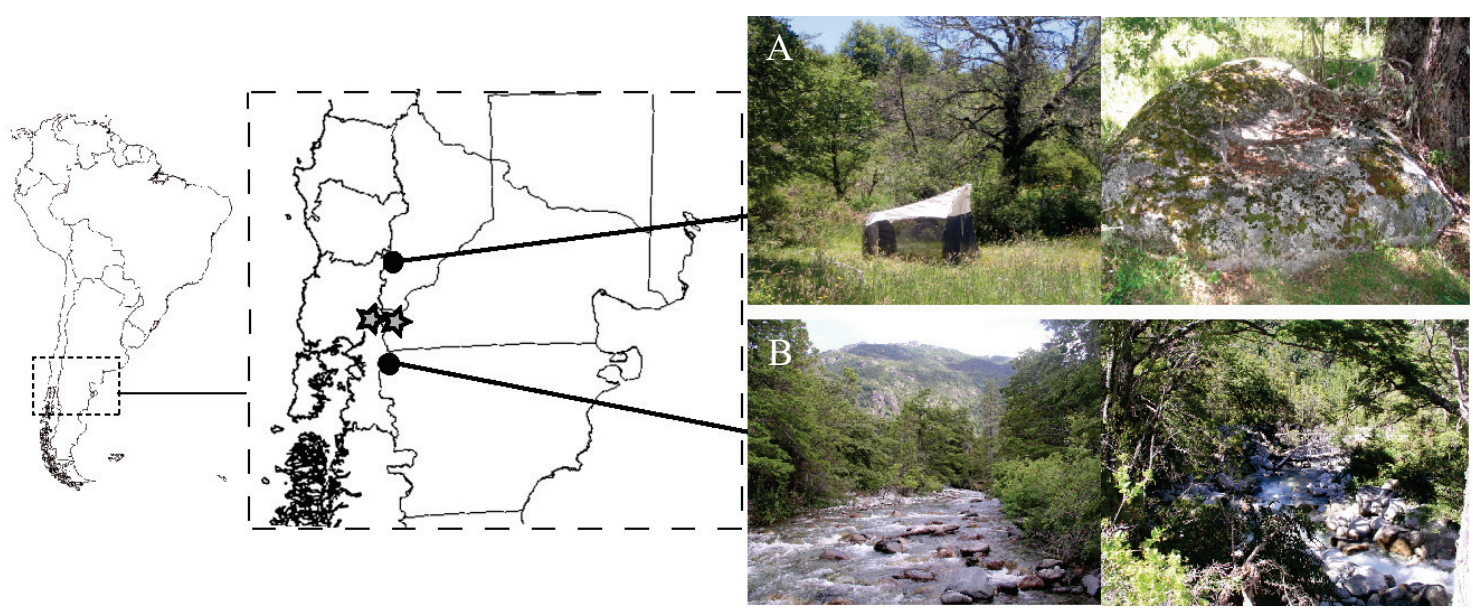

Fig. 19. Distribution records of Apsil pennata. 19A. PN Lanín, Lago Quillén, Argentina. 19B. PN Lago Puelo, Los Hitos, Argentina. Black dots: new records; gray stars: previous known records.

Legs. All legs black with grey pollinosity. Fore femur with a row of strong posterodorsal, and a row of strong posteroventral setae decreasing in size toward apex; fore tibia with one median posterior seta, base of tibia and first tarsomere with a brush of yellow setae (Fig. 3). Mid femur with 2 fine ventral setae at middle; a row of fine anterodorsal setae on basal third, and 2 preapical setae on posterodorsal to posterior surface; mid tibia with one anterodorsal and one posterior median setae. Hind femur with a complete row of anterodorsal and a row of anteroventral setae on apical half; hind tibia with one long and fine anterodorsal supramedian seta, 4 long and fine anteroventrals on apical half, and a long and fine posterior seta on apical two thirds.

Abdomen (Fig. 5). Grey with sub-triangular lateral darkbrown marks on tergites $1+2-4$; tergite 5 grey with a central dark-brown line. Sternite 1 bare.

Terminalia. Tergites 6, 7 and 8 divided into 2 long, fine and parallel scletotized plates; epiproct developed, cercus long (Fig. 6). Sternites 6 and 7 small; sternite 8 divided into 2 small and linear sclerotized plates, each with setulae on distal margin; hypoproct rounded, weakly sclerotized and setulose (Fig. 7). Three spermathecae (Fig. 8).

Male (Figs. 9-13). Length. Body: 4.7-4.9 mm, Wing: 4.5$4.7 \mathrm{~mm}$.

Differs from female as follows: Fore tibia with long, flatted, and strong posterodorsal, dorsal, and anterodorsal setae on apical half; first tarsomere strongly modified, expanded and flattened (Fig. 11). Abdomen. Tergite 5 grey with subtriangular lateral dark-brown marks (Fig. 13). Terminalia. Sternite 5 not uniformly sclerotized; setae restricted to apical margin (Fig. 14). Sternite 6 with both arms, left arm interrupted close to articulation (Figs. 15, 16). Cercal plate and surstyli straight and long (Figs. 17, 18). Hypandrium tubular and aedeagus as in figure 18 .

Examined material. ARGENTINA: CHUBUT: 3 females, 3 males, Los Hitos, Parque Nacional Lago Puelo, I-2011. Mulieri \& Patitucci leg. (MACN). NEUQUEN: 6 females, 2 males, Lago Quillén, Parque Nacional Lanín, I-2013. Patitucci leg. (MACN).
Distribution (Fig. 19). ARGENTINA: CHUBUT, Parque Nacional Lago Puelo, Los Hitos (new record); NEUQUÉN, Parque Nacional Lanín, Lago Quillén (new record); RÍO NEGRO, Bariloche. CHILE: X REGIÓN DE LOS LAGOS, Casa Pangue.

Remarks. Male and female specimens studied in this work were collected together with a hand net from two different kinds of habitats. Specimens from Parque Nacional Lago Puelo were caught on the rocks at the margin of "Los Hitos" stream (280 m.a.s.1.) (Fig. 19B). On the other hand, specimens collected in Parque Nacional Lanín (993 m.a.s.1.) were caught on rocks in forest edge (Fig. 19A). Also these specimens were observed walking over the moss while eating acari.

In order to include the female of $A$. pennata in the key for Apsil species by Couri (2006), we propose a modification in couplet 7 as follows:

7. Fore femur with the posteroventral row of setae much stouter than the posterodorsal one ............................... 7 ,

-. Fore femur with the posteroventral row of setae not stouter than the posterodorsal one .............................................. 8

7'. Scutellum grey. Tarsi yellow A. apicata Malloch -. Scutellum dark-brown to black. Tarsi black. Female ........ A. pennata Malloch

\section{ACKNOWLEDGEMENTS}

The authors are grateful to Adrian Pont and Claudio J.B. de Carvalho for the appropriate comments and suggestions. We thank National Parks administration, and all the staff of the PN Lanín and PN Lago Puelo, for their collaboration; María Sofía Olea, Pablo Mulieri, and Juan Carlos Mariluis for their valuable help in the field work. We also thank Luis Compagnucci for the help with the photos. Financial support for this study was partially provided by CONICET (PIP $\mathrm{N}^{\circ} 11220090100548$ ) and FONCyT (Grant PICT $2008 \mathrm{~N}^{\circ}$ 0094, Grant PICT 2011 N $^{\circ}$ 0490). 


\section{REFERENCES}

Cabrera, A.L. \& Willink, A. 1973. Biogeografía de América Latina. Washington, DC, Departamento de Asuntos Científicos de la Secretaria General de la Organización de los Estados Americanos, 120 p.

Couri, M.S. 2000. A revision of the genus Apsil Malloch (Diptera, Muscidae, Coenosiinae, Coenosiini). Studia Dipterologica 7: 45-57.

Couri, M.S. 2002. A new species of Apsil Malloch from Chile (Diptera, Muscidae). Revista Brasileira de Zoologia 19: 105-108.

Couri, M.S. 2006. Taxonomy and morphology of Apsil Malloch (Diptera, Muscidae, Coenosiinae, Coenosiini) with new records, description of a new species and a key to identification. Revista Brasileira de Entomologia 50: 232-239.

Cumming, J.M. \& Wood, D.W. 2009. Adult morphology and terminology, p. 9-50. In: Brown, B.V., Borkent, A., Cumming, J.M., Wood, D.M., Woodley, N.E. \& Zumbado, M. (eds.). Manual of Central American
Diptera, Volume 1. Ottawa, National Research Council of Canada Publishers, $\mathrm{xi}+714 \mathrm{p}$.

de Carvalho, C.J.B. \& Couri, M.S. 2002. Cladistic and biogeographic analyses of Apsil Malloch and Reynoldsia Malloch (Diptera: Muscidae) of southern South America. Proceedings of the Entomological Society of Washington 104: 309-317.

de Carvalho, C.J.B. \& Couri, M.S. 2011. Biogeografia de Muscidae (Insecta, Diptera) da América do Sul, p. 277-298. In: Carvalho, C.J.B. \& Almeida, E.A.B. (eds). Biogeografia da América do Sul. Padrões \& Processos. São Paulo, Roca, xii+306 p.

Edwards, F.W. 1929. Introduction, p. vii-xiv. In: Alexander, C.P. Diptera of Patagonia and South Chile. Part 1-Crane-flies. London, British Museum (Natural History) Publisher, 240 p.

Malloch, J.R. 1929. Exotic Muscaridae (Diptera) - XXVI. Annals and Magazine of Natural History (10) 4: 97-120.

Malloch, J.R. 1934. Muscidae, p. 171-346. In: Diptera of Patagonia and South Chile. Part 7 (2). London, British Museum (Natural History) Publisher.

Received 15 July 2013; accepted 31 August 2013

Associate Editor: Rodrigo S. M. Feitosa 